\title{
Pre-service mathematics teachers' pedagogical content knowledge regarding student mistakes on the subject of circle
}

\author{
Zeki Aksu \\ Department of Mathematics Education, Artvin Coruh University, Turkey
}

\begin{tabular}{l} 
Article Info \\
\hline Article history: \\
Received Jun 16, 2019 \\
Revised Jul 13, 2019 \\
Accepted Aug 28, 2019 \\
\hline Keywords: \\
Circle \\
Pedagogical content knowledge \\
Pre-service teacher \\
Understanding the student
\end{tabular}

\begin{abstract}
The aim of this study is to examine the pre-service teachers' pedagogical content knowledge about the subject of circle in the context of knowing the source of students' mistakes and offering correct solutions. The participants of the study consisted of 30 pre-service teachers who were studying in the last grade of Department of Mathematics Education. In the study, the data were collected through open-ended questions with the qualitative approach. It was determined that the pre-service teachers were not at the desired level in terms of identifying the source of students' mistakes and proposing correct solutions. It is very important for pre-service teachers to be aware of their pedagogical content knowledge levels for their professional careers.
\end{abstract}

Copyright () 2019 Institute of Advanced Engineering and Science. All rights reserved.

\section{Corresponding Author:}

Zeki Aksu,

Department of Mathematics Education,

Artvin Coruh University,

08100, Artvin, Turkey.

Email: zekiaksu25@artvin.edu.tr

\section{INTRODUCTION}

Geometry is one of the most important branches of mathematics. Thus, geometry enhances students' reasoning, problem solving and proving skills and increases their critical thinking capacities [1]. Geometry achievements are included in all grade levels of the elementary, secondary and high school mathematics curricula. As in mathematics, subjects are not independent from each other in geometry. For this reason, the problems experienced by students in a subject will cause them to experience difficulties in the following subjects. In addition, it was observed that students in Turkey exhibited low performance in geometrical subjects in the exams held at both international and national levels [2]. In the teaching of geometry, it is very important for students to learn all the concepts conceptually from the first years onward.

In the teaching of circle and circular region, which starts with the naming of circle by students in the first grade of elementary school, is one of the important subjects in geometry. Hence, it was seen that students in various classes at elementary and secondary schools had difficulties in learning the subject of circles and circular region [3-5]. There may be many reasons why students have difficulty in learning such topics. Failure to realize conceptual learning will be a problem for all teaching levels and will affect students' entire lives of learning. It is thought that the non-realization of conceptual learning about circle can directly affect the post acquired geometrical information. It is envisaged that it will be difficult to correct this problem, which will be experienced especially at the secondary school level, in the future. The students continue to experience problems in the following years due to their inability to adequately interpret the concepts about circle and having misconceptions. In the research of Güngörmüş [6], it was shown that secondary school students had difficulty in remembering the preliminary information about the concept of circle. Similarly, Akuysal [7] found that elementary 7th grade students could not express geometrical concepts and understand the relationships between them although they recognized them. Teachers and pre- 
service teachers have great responsibility for identifying the difficulties experienced by the students about circle and guiding their conceptual understanding. What is important here is that teachers and pre-service teachers should be aware of the source of the problems experienced by students and find appropriate solutions. Accordingly, in this study, the pedagogical content knowledge of secondary school pre-service mathematics teachers about the subject of circle, was examined in terms of identifying students' mistakes and correcting these mistakes.

PCK, as an asset that must be present in teachers and pre-service teachers, was studied by many researchers after it was brought into the literature by Shulman [8]. It was determined that PCK had a central role in the development of teachers [9-12] and pre-service teachers' pedagogical content knowledge and development began to be examined [13-19]. Examining the development of pre-service teachers' pedagogical content knowledge is important in terms of developing pre-service teacher training programs and pre-service teachers' qualifications [20-21].

Pedagogical content knowledge is directly related to mathematics teaching competencies of teachers or pre-service teachers [22]. Hammack and Ivey [23] found that teaching competency was closely related to pedagogical content knowledge. Accordingly, there is a positive relationship between teaching competency and pedagogical content knowledge [24-25].

In the undergraduate program of elementary mathematics teaching last updated in 2018-2019 in Turkey by the qualities Higher Education Council (Yuksek Ogretim Kurumu, YOK), an emphasis was placed on educating pre-service teachers who are qualified in terms of content knowledge, general culture and pedagogical aspects, highly motivated, made sense of the basic values and ideals of the society and had high. In addition, it was specified that the Teacher Strategy Document (2017-2023) put into force in 2017 by the Turkish Ministry of the National Education (Milli Egitim Bakanlıg1, MEB) and the redefined Teaching Profession General Competencies were considered as a basis during the preparation of the content of the program. Teaching profession general competencies as shown in Table 1. As seen in the table, both MEB and YOK give great importance to having a good level of pedagogical content knowledge in pre-service teachers.

Table 1. Teaching profession general competencies (MEB general directorate of teacher training and

\begin{tabular}{|c|c|c|}
\hline A Professional Knowledge & B Professional Skill & C Attitudes and Values \\
\hline A1. Content Knowledge & B1. Educational Planning & $\begin{array}{l}\text { C1. National, Spiritual and Universal } \\
\text { Values }\end{array}$ \\
\hline $\begin{array}{l}\text { Has advanced institutional, } \\
\text { methodological and factual } \\
\text { knowledge in the content to cover the } \\
\text { interrogative perspective. }\end{array}$ & Plans educational processes effectively. & $\begin{array}{l}\text { Observes national, spiritual and } \\
\text { universal values. }\end{array}$ \\
\hline A2. Content Educational Knowledge & B2. Creating Learning Environments & C2. Approach to Students \\
\hline $\begin{array}{l}\text { Has a command of the curriculum } \\
\text { and pedagogical content knowledge? }\end{array}$ & $\begin{array}{l}\text { Prepares healthy and safe learning } \\
\text { environments in which effective } \\
\text { learning can take place and appropriate } \\
\text { teaching materials for all the students. }\end{array}$ & $\begin{array}{l}\text { Demonstrates a supportive attitude for } \\
\text { students' development. }\end{array}$ \\
\hline A3. Knowledge of Legislation & $\begin{array}{l}\text { B3. Managing the Learning and Teaching } \\
\text { Process }\end{array}$ & C3. Communication and Cooperation \\
\hline \multirow[t]{3}{*}{$\begin{array}{l}\text { Acts in accordance with the } \\
\text { legislation regarding duties, rights } \\
\text { and responsibilities as an individual } \\
\text { and teacher. }\end{array}$} & $\begin{array}{l}\text { Conducts the teaching and learning } \\
\text { process effectively. }\end{array}$ & $\begin{array}{l}\text { Establishes effective communication } \\
\text { and cooperation with students, } \\
\text { colleagues, families and other } \\
\text { stakeholders of education. }\end{array}$ \\
\hline & B4. Measurement and Evaluation & $\begin{array}{l}\text { C4. Personal and Professional } \\
\text { Development }\end{array}$ \\
\hline & $\begin{array}{l}\text { Uses measurement and evaluation } \\
\text { methods, techniques and tools in } \\
\text { accordance with the purpose. }\end{array}$ & $\begin{array}{l}\text { Makes self-evaluation and participates } \\
\text { in activities related to personal and } \\
\text { professional development. }\end{array}$ \\
\hline
\end{tabular}

In this study, the problems experienced by the students in the subject of circle and the pedagogical content knowledge which is seen as general professional competence in pre-service teachers were taken into consideration. Therefore, in this study, pedagogical content knowledge of secondary school pre-service mathematics teachers about circle is discussed in the context of the component of understanding the student.

\section{RESEARCH METHOD}

In this study, the case study method which is based on qualitative approach was used as it was aimed to reveal the secondary school pre-service mathematics teachers' written explanations, their approaches to students' mistakes and their solution proposals to eliminate these mistakes and to enable 
pre-service teachers to examine the subject of circle in detail in the context of their pedagogical content knowledge. This study was conducted with 30 pre-service teachers who were studying in the last grade of Department of Mathematics Education of a state university.

In this research, data collection process consists of two stages. In the first stage, a test consisting of 7 open-ended questions was prepared in order to examine the current learning of secondary school students about circle. This test was applied to a total of 130 students including 7 th and 8 th grade students.

In the second stage, the answers given by the students were examined and the mistakes made by the students about circle were determined for the data collection tool to be applied to the pre-service teachers. Then, five of these mistakes were selected by considering expert opinions. This form prepared by the researcher was given to the pre-service teachers in writing. Moreover, the pre-service teachers were given sufficient time to answer the questions in detail. The data obtained from the study were analyzed through the descriptive analysis technique.

\section{RESULTS AND ANALYSIS}

In this section, findings obtained from the analysis of the pre-service teachers' ability to determine the students' mistakes and their written educational explanations for the elimination of these mistakes are stated.

Pre-service mathematics teachers have completed the School Experience-I course in the seventh semester of their undergraduate education and take the "Teaching Practice" course in the eighth semester requiring them to give lessons in the schools of practice. Prior to this, they took many of the pedagogical, content and teaching-oriented courses. The data of this study were collected while the pre-service teachers were attending the course of "Teaching Practice". Pre-service teachers were first asked the question below to make an assessment.

"Can you assess the experiences, which you gained in the course of teaching practice in this semester within the scope of faculty-school cooperation considering the parts constituting this course (observations, in-class implementations, feedbacks or returns, practice teachers, school's students, teaching staff etc.), in the widest sense?

All the pre-service teachers stated that the "teaching practice" course made a lot of contribution to them professionally. They talked about the importance of seeing the classroom environment and experiencing giving a lecture like a real mathematics teacher by leaving their studentship aside. In addition, it was stated as efficient in terms of detecting students' mistakes.

P.T. 5: The course of teaching practice was a useful experience for us, pre-service teachers. I think it would have been useful if we had been given this course in earlier years due to improving ourselves better, identifying the student's mistakes in the best way and many other similar reasons, because the practices with students in a real classroom environment present many pluses for us. In addition to the shortcomings of the students, I learned my own shortcomings and tried to correct them.

P.T. 12: In the classroom, I learned about the students' reactions to questions, misconceptions, what they liked, and the impact of the materials on the lesson, and the need for giving students timely feedback.

P.T. 24: The teaching practice was a real experience for me. It was nice to be in one-to-one interaction with the student and feel the school and class atmosphere. I see it as an important step to teach mathematics and get it liked.

As seen from the explanations, the pre-service teachers stated that the teaching practice was beneficial to get to know the students better and to be able to understand the students' mistakes. It is also seen from this point that the time of the study was chosen correctly in terms of the pre-service teachers.

In the other questions directed to the pre-service teachers, explanations were required about the problems faced by the secondary school students about circle. Here, the purpose is to determine whether the pre-service teachers correctly identified the students' mistakes and whether they provided the correct solution proposals for eliminating these mistakes. Frequency and percentage distribution of the answers related to questions as shown in Table 2.

Table 2. Frequency and percentage distribution of the answers related to questions

\begin{tabular}{|c|c|c|c|c|c|c|c|c|}
\hline & \multicolumn{2}{|c|}{$\begin{array}{l}\text { Determining mistake } \\
\text { incomplete }\end{array}$} & \multicolumn{2}{|c|}{$\begin{array}{c}\text { Determining mistake } \\
\text { complete }\end{array}$} & \multicolumn{2}{|c|}{$\begin{array}{c}\text { Proposal for incomplete } \\
\text { solution }\end{array}$} & \multicolumn{2}{|c|}{$\begin{array}{c}\text { Proposal for complete } \\
\text { solution }\end{array}$} \\
\hline & $\mathrm{f}$ & $\%$ & $\mathrm{f}$ & $\%$ & $\mathrm{f}$ & $\%$ & $\mathrm{f}$ & $\%$ \\
\hline Question 1 & 8 & 27 & 22 & 73 & 12 & 40 & 18 & 60 \\
\hline Question 2 & 20 & 67 & 10 & 33 & 11 & 37 & 19 & 63 \\
\hline Question 3 & 2 & 7 & 28 & 93 & 14 & 47 & 16 & 53 \\
\hline Question 4 & 10 & 33 & 20 & 67 & 18 & 60 & 12 & 40 \\
\hline Question 5 & 6 & 20 & 24 & 80 & 22 & 73 & 8 & 27 \\
\hline
\end{tabular}


When Table 2 is examined, it can be said that the pre-service teachers were successful in identifying the mistake in question 1 correctly and proposing the correct solution. In the answers given by pre-service teachers, it was seen that they were aware of the students' problem with pi $(\pi)$ and proposed correct solutions. However, it was found interesting that the pre-service teachers experienced difficulties in identifying the source of the mistake in question 2, because, in the first question, the pre-service teachers stated that students had problems in understanding the pi as they considered pi as a variable. Furthermore, in the second question, the pre-service teachers made an explanation by treating pi as a variable themselves.

Question 1: What don't secondary school students know the mathematical meaning of Pi $(\pi)$ or express it mathematically? What kind of a path should be followed to overcome this problem?

P.T. 4: The reason is that pi is seen as a variable like $\mathrm{x}$.

Question 2: The students were asked the following question: graze in?"

"A lamb is tied to a tree with a rope. What data is needed to find the largest area the lamb can

Some of the students answered that they would need the radius (length of rope) and pi. Discuss the answer and the reason for such an answer.

P.T. 4: Yes, he answered correctly. The length of the rope represents the radius. So, if we know the length of the rope and $\mathrm{pi}$, we can find the area.

The majority of the pre-service teachers explained the source of the mistake in question 3 correctly.

Question 3: Circle is similar to round. For example, discuss what you can tell about the conceptual knowledge of a student who expresses and exemplifies circle as a "watch, bottle cap, jar lid".

P.T. 24: The student had a misconception by associating everything round he saw with circle. He could not understand the difference between circular region and circle.

However, when the solution proposals were examined, it was seen that they could not make correct explanations at the same level. In general, they made statements such as "definitions should be read again".

P.T. 17: The definitions of circle and circular region should carefully be read again and the examples given should be revised by the student.

Although pre-service teachers were successful in identifying the mistake correctly in the 4th and 5th questions (related to the area of circular region and measurement and length of circular arc), they did not have the same success in proposing the correct solution.

\section{DISCUSSION}

In this study, the pre-service mathematics teachers' solution proposals about what the mistakes made by the students in questions related to the subject of circle could be and how these mistakes could be corrected were examined. On the basis of the findings obtained from the study, it has been found out that the majority of the pre-service teachers stated the source of the mistakes made by the students about circle correctly, although partially. According to this result achieved in the study, it can be said that pre-service teachers' status of knowing the source of the mistake related to students' mistakes is at a level which can moderately be considered as good. According to Shulman [8], knowledge of understanding the student or identifying the source of the students' mistake is an important stage of the pedagogical content knowledge. In order to be able to identify the conceptual mistakes of the students, the conceptual knowledge of the preservice teacher must be complete. When the explanations of the pre-service teachers who could not identify the source of the mistake are examined, it is seen that there is a problem in the pre-service teacher's own conceptual knowledge. Bekdemir [27] discovered in the study conducted with pre-service classroom teachers that there were problems in the conceptual knowledge of the pre-service teachers about circle. According to the results of Özerbaş and Kaygusuz's [5] study, it was found that students had misconceptions about determining the properties of circular region and they were confused about the concepts of circle and circular region. It was stated in Toluk-Uçar's [28] study that pre-service teachers could make use of escape routes in order to help the student to learn the rule by heart more easily if they did not have an adequate level of mathematical understanding.

According to the findings of the research, it was seen that the pre-service teachers' success in determining the source of the mistakes could not be exhibited in proposing correct solutions. The statements made by the pre-service teachers were generally in the form of repetition of the rules. It was seen that the number of the pre-service teachers who made explanations at the conceptual level and proposed the correct solution for eliminating the mistake was not at the desired level for the other questions except for questions 4 and 5. These results are in parallel with the study results of Gökbulut [29], Gökkurt, Şahin, Soylu and Soylu [30] and Gökkurt, Şahin, Soylu and Doğan [31] examining the instructional explanations of the pre-service teachers about the geometrical objects. According to the findings of Toluk-Uçar [28], it was discovered that 
pre-service classroom and mathematics teachers did not have enough mathematical knowledge to be able to carry out teaching as intended by the Elementary Mathematics Curriculum.

In instructional explanations, in addition to explaining how to apply the rules, expressions that had no mathematical basis were frequently mentioned as well. While few pre-service teachers could made explanations at the conceptual level, almost no pre-service teachers used the meaning and reasons underlying the rules of the procedures in their explanations.

Understanding the student and proposing the correct solutions for students' mistakes are significant components that should be researched while determining the pedagogical content knowledge of the preservice teachers. When approached within the scope of these components, it was seen that the pre-service teachers' pedagogical content knowledge was not at the desired level. In the researches, it was seen that the pre-service teachers' pedagogical content knowledge about the examined subject of mathematics was not sufficient [13, 28, 30-33].

\section{CONCLUSION}

Considering that the pre-service mathematics teachers took almost all the undergraduate courses and reached the end of the teaching practice, their pedagogical content knowledge (PCK) would be expected more qualified. It was not easy to determine the PCKs of teachers or pre-service teachers. For this reason, it is necessary to use different measurement methods and make long-term investigations in order to reach more accurate results. When viewed in the context of the component of understanding the student, experience in teaching profession stands out. Therefore, it will be useful to re-examine the pedagogical content knowledge of the pre-service teachers after they start their career. However, it is very important for pre-service teachers to be aware of their own pedagogical content knowledge levels in terms of self-improvement.

\section{REFERENCES}

[1] National Council of Teachers of Mathematics [NCTM], "Principles and standards for school mathematics," Reston, VA: The National Council of Teachers of Mathematics, 2000.

[2] M.H. Sar1 and N. Tertemiz, "The effect of geometry activities structured according to Dienes principles on student achievement and retention in 4th grade of primary school (in Turkey)," Eğitim ve Bilim, vol. 42(190), pp. 1-23, 2017.

[3] Z. Aksu and Ü. Kul, "Conceptual knowledge of middle school students about circle: The case of artvin province (in Turkey)," International Artvin Symposium, Artvin, Oct 2018.

[4] G.G. Cantimer and S. Şengül, "Misconceptions and mistakes of middle school 7th and 8th grade students about circle (in Turkey)," Gazi Eğitim Bilimleri Dergisi, vol. 3(1), pp. 17-27, 2017.

[5] M.A. Özerbaş and C. Kaygusuz, "Determination of misconceptions related to circle sub-learning area (in Turkey)," Gazi Üniversitesi Endüstriyel Sanatlar Eğitim Fakültesi Dergisi, vol. 28, pp. 78-94, 2012.

[6] L. Güngörmüş, "Misconceptions in secondary mathematics teaching," Yayımlanmamış yüksek lisans tezi. Atatürk Üniversitesi Fen Bilimleri Enstitüsü, Erzurum, 2002.

[7] N. Akuysal, "The misconceptions of elementary 7th grade students in geometric concepts in 7th grade units Unpublished doctoral dissertation (in Turkey)," Selçuk Üniversitesi Fen Bilimleri Enstitüsü, Konya, 2007.

[8] L.S. Shulman, "Those who understand: Knowledge growth in teaching," Educational Researcher, vol. 15(2), pp. 4-14, 1986.

[9] H. Chick and M. Baker, "Pedagogical content knowledge for teaching primary mathematics: A case study of two teachers," 2006.

[10] H.C. Hill, D.L. Ball, and S.G. Schilling, "Unpacking pedagogical content knowledge: Conceptualizing and measuring teachers' topic-specific knowledge of students," Journal for Research in Mathematics Education, vol. 39(4), pp. 372-400, 2008.

[11] E. Lee, M.N. Brown, J.A. Luft, and G.H. Roehrig, "Assessing beginning secondary science teachers' pck: Pilot year results," School Science and Mathematics, vol. 107(2), pp. 52-60, 2007.

[12] R.G. Smith, "Developing professional 1dentities and knowledge: Becoming primary teachers. teachers and teaching," Theory and Practice, vol. 13(4), pp. 377-397, 2007.

[13] Z. Aksu and A. C. Konyalığlu, "Elementary school teacher candidates' pedagogical field knowledge about fractions (in Turkey)," Kastamonu Eğitim Dergisi, vol. 23(2), pp. 723-738, 2015.

[14] D.L. Ball, "The mathematical understandings that prospective teachers bring to teacher education," The Elementary School Journal, vol. 90(4), pp. 449-466, 1990.

[15] R. Even, "Subject-matter knowledge and pedagogical content knowledge: Prospective secondary teachers and the function concept," Journal for Research in Mathematics Education, vol. 24(2), pp. 94-116, 1993.

[16] Ö. Şahin, B. Gökkurt and Y. Soylu, "Examining prospective mathematics teachers' pedagogical content knowledge on fractions in terms of students' mistakes," International Journal of Mathematical Education in Science and Technology, vol. 47(4), pp. 531-551, 2016. 
[17] E. Türnüklü, "Relationship between pedagogical field knowledge and mathematical field knowledge of pre-service mathematics teachers (in Turkey)," Eurasian Journal of Educational Research, vol. 21, pp. 234-247, 2005.

[18] S. Yeşildere and H. Akkoç, "Investigation of pedagogical field knowledge related to number patterns of pre-service mathematics teachers in the context of subject specific strategies (in Turkey)," Ondokuz Mayı Üniversitesi Ĕgitim Fakültesi Dergisi, vol. 29(1), pp. 125-149, 2010.

[19] S. Yeşildere and E. Türnüklü, "Examination of students' mathematical thinking and reasoning processes," Ankara University, Journal of Faculty of Educational Sciences, vol. 40(1), pp. 181-213, 2007.

[20] W.A. O'Hanlon, "Characterizing the pedagogical content knowledge of pre-service secondary mathematics teachers," Unpublished Doctoral Dissertation, Illıno1s State University, 2010.

[21] J.T. Sowder, "The mathematical education and development of teachers," In F.K. Lester (Ed.), Second Handbook of Research on Mathematics Teaching and Learning, pp. 157-224, 2007.

[22] National Academy of Engineering and National Research Council [NAE \& NRC], "STEM integration in K-12 education: Status, prospects, and an agenda for research," Washington: National Academies Press, 2014.

[23] R. Hammack and T. Ivey, "Examining elementary teachers' engineering self-efficacy and engineering teacher efficacy," School Science and Mathematics, vol. 117(1-2), pp. 52-62, 2017.

[24] G.M. Richardson, L.L. Byrne and L.L. Liang, "Making learning visible: Developing preservice teachers' pedagogical content knowledge and teaching efficacy beliefs in environmental education," Applied Environmental Education \& Communication, vol. 17(1), pp. 41-56, 2018.

[25] M.M. Thomson, D. DiFrancesca, S. Carrier and C. Lee, "Teaching efficacy: Exploring relationships between mathematics and science self-efficacy beliefs, PCK and domain knowledge among preservice teachers from the United States," Teacher Development, vol. 21(1), pp. 1-20, 2017.

[26] MEB, "Öğretmenlik Mesleği Genel Yeterlikleri," 2017, Retrieved from: http://oygm.meb.gov.tr adresinden 12.06.2019.

[27] M. Bekdemir, "Evaluation of teacher candidates' concept and process knowledge about circle and circle subjects (in Turkey)," Hacettepe Üniversitesi Eğitim Fakültesi Dergisi, vol. 43(43), pp. 83-95, 2012.

[28] Z. Toluk-Uçar, "Pedagogical content knowledge of teacher candidates: Instructional explanations (in Turkey)," Turkish Journal of Computer and Mathematics Education, vol. 2(2), pp. 87-102, 2011.

[29] Y. Gökbulut, "Pre-service teachers' pedagogical field knowledge about geometric objects, (in Turkey)," Unpublished doctoral dissertation, Gazi Üniversitesi Eğitim Bilimleri Enstitüsü, Ankara, 2010.

[30] B. Gökkurt, Ö. Şahin, Y. Soylu, and C. Soylu, "Investigation of pre-service teachers' pedagogical field knowledge about fractions in terms of student errors (in Turkey)," International Online Journal of Educational Sciences, vol. 5(3), pp. 719-735, 2013.

[31] B. Gökkurt, Ö. Şahin, Y. Soylu, and Y. Doğan, "Pre-service teachers' pedagogical content knowledge regarding student mistakes on the subject of geometric shapes," Elementary Education Online, vol. 14(1), pp. 55-71, 2015.

[32] M. Işı1ksal, "A study on elementary mathematics teacher candidates' field and pedagogical content knowledge about multiplication and division in fractions (in Turky)," Unpublished doctoral dissertation, Orta Doğu Teknik Üniversitesi, Fen Bilimleri Enstitüsü, Ankara, 2006.

[33] K.E. Leong, C.C. Meng, A. Rahim, and S. Syrene, "Understanding malaysian pre-service teachers mathematical content knowledge and pedagogical content knowledge," Eurasia Journal of Mathematics, Science \& Technology Education, vol. 11(2), pp. 363-370, 2015.

\section{BIOGRAPHY OF AUTHOR}

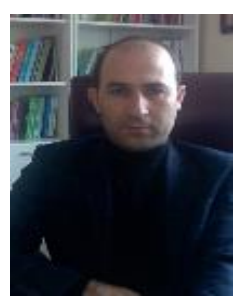

Zeki Aksu is a Doctor of Mathematics Education at Artvin Coruh University, Faculty of Education in Artvin/Turkey. He published articles and presented at several scientific conferences related to mathematics education. His research interests include pre-service teacher training, pedagogical content knowledge, mathematics education, teacher education. 